\title{
Soybean Meal Incorporation in Diet Improves the Growth and Survival Performances of Juveniles of Nile Tilapia (Oreochromis niloticus) in Rural Area of Senegal
}

\author{
Ly Mouhamadou Amadou ${ }^{1}$, Sarr Serigne Modou ${ }^{2, *}$, Ndiaye Nanthiely ${ }^{2}$ \\ ${ }^{1}$ Training and Research Unit of Agronomic Sciences, Aquaculture and Food Technologies (UFR S2ATA), Gaston Berger University of Saint- \\ Louis (UGB), Saint-Louis, Senegal \\ ${ }^{2}$ Higher Institute of Agricultural and Rural Training (ISFAR), Alioune DIOP University (UAD) of Bambey, Bambey, Senegal
}

Email address:

serignemodou.sarr@uadb.edu.sn (S. S. Modou)

${ }^{*}$ Corresponding author

To cite this article:

Ly Mouhamadou Amadou, Sarr Serigne Modou, Ndiaye Nanthiely. Soybean Meal Incorporation in Diet Improves the Growth and Survival Performances of Juveniles of Nile Tilapia (Oreochromis niloticus) in Rural Area of Senegal. American Journal of Agriculture and Forestry. Vol. 9, No. 3, 2021, pp. 122-126. doi: 10.11648/j.ajaf.20210903.14

Received: April 22, 2021; Accepted: May 12, 2021; Published: May 26, 2021

\begin{abstract}
This study was conducted to investigate if the soybean meal incorporation in locally made diet will improves the growth and survival performances of fry of Nile tilapia in rural area of Senegal. A completely randomized design with four treatments of soybean meal incorporation $(0,15,30$ and $32 \%$ ) was utilized in this study. The formulated diets had $35 \%$ crude protein content. The fingerlings were fed to satiation two times a day at 9 AM and 4 PM for 56 days. The analysis of variance showed final weight, specific growth rate and percent weight gain of fish increased significantly $(P<0.05)$ as soybean meal was added up to $30 \%$ level. The feed conversion ratio values were high and decreased significantly $(P<0.05)$ with the increase of soybean meal in the diet, ranging from 2.17 to 2.90 . There was also a significant difference $(P<0.05)$ in survival among treatment, survival ranged from $62.22 \%$ to $91.11 \%$. Except temperature, the water quality parameters were in the optimal range of $O$. niloticus. In conclusion, the result of this study shows that soybean meal can be added to up to $30 \%$ in the $O$. niloticus diet, without affecting growth performances.
\end{abstract}

Keywords: Plant, Protein, Glycine max, Fish Farm, Diet

\section{Introduction}

The fish-farming sector has not yet reached a viable economic dimension in Africa, either in terms of volume or in terms of the place of this activity in other production systems [1]. Oreochromis niloticus, is an important fish for aquaculture production in the north of Senegal. This species is able to tolerate environmental stress, reproduce easily, grow at a fast rate coupled with a high market demand [2]. Fish feed is the key component of aquaculture production and it's expensive cost caused failure in many farms. Fish meal is considered as the most nutritious animal ingredients in fish feed formulation but his cost makes many researches to turn on soybean meal which is the most nutritious plants ingredients in term of protein and it's widely used diet [3]. As in most aquaculture programs, reducing feeds cost is a permanent concern due to its direct impact on the cost of production.

In order to reduce the feed cost, the use of fish meal has to be reduced. This can be achieved by using alternative protein sources in fish diets mainly plant protein ones. [4-5] reported a wide range of agro-industrial by products used in fish feed. Moreover, the nutritional requirement of $O$. niloticus is very well documented, to achieve good growth. Normally, protein requirements of $O$. niloticus differ with each life stage of the fish, for fry dietary protein levels ranging from $36-50 \%$ have shown to produce maximum growth, for juveniles $29-40 \%$ has been determined to produce optimal growth and young adult fish 27-35\% protein appears to be optimal [6].

Also, the successful use of plant ingredients for $O$. niloticus has been reported by several authors [6, 7]. There are differences in the maximum dietary levels of soybean 
meal tolerance in different species [8-13]. This study considers using small amount of fish meal and different plant ingredients such as corn flour, peanut cake and soybean meal in mixture will improve growth and reduce the cost of the feed in rural area. Therefore, the soybean meal was used gradually in this study. The aim of this study was to evaluate if the soybean meal incorporation in farm made diet will improves the growth and survival performances of fry of Nile tilapia in rural area of Senegal.

\section{Material and Method}

\subsection{Experimental Design}

The research experiment was conducted at the 3FT integrated farm at the North of Senegal, between November to Mars 2020. Fish were obtained from the Aquaculture department of the Gaston Berger University, Saint-Louis, Senegal. The fish were acclimated in one tank for one week. At the beginning of the experiment, fingerlings were selected randomly and stocked 12 experimental unit at a stocking density of 15 fish per unit of $0.67 \mathrm{~m}^{3}$. The experimental units are made of fiberglass tank, with meshed hole, where the water was circulating from one unit to another one. The water was changed up to $50 \%$ each week. The experimental fish were fed to satiation two times a day at 9h: 00 and 16h: 00 for 8 weeks.

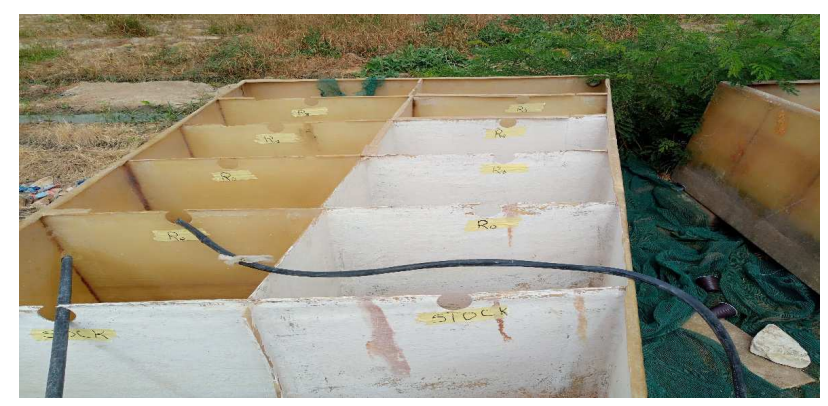

Figure 1. Experimental tanks (CLy, 2021).

\subsection{Experimental Diet}

Four isonitrogenous diets of $35 \%$ crude protein with elevated soybean meal, at $0,15,30$ and $60 \%$, were prepared for the experiment. Fishmeal corn flour, peanut cake and soybean meal were finely grounded and poured through a sieve of $425 \mu \mathrm{m}$ mesh. Vitamin and mineral premix were mixed separately with the cellulose and the binder before being added to the main ingredient mixture. Diets were supplemented with fish oil after the addition of water. The semi-moist mixture was then pressure pelleted in the food grinder using a $2 \mathrm{~mm}$ die, dried at $35^{\circ} \mathrm{C}$ for two days, cut to desired sizes, packaged into plastic bag and stored frozen until its usage. The diets were screened prior to feeding in order to remove the fines.

\subsection{Measurements}

Temperature $\left({ }^{\circ} \mathrm{C}\right)$, dissolved oxygen $\left(\mathrm{O}_{2}, \mathrm{mg} \mathrm{l}^{-1}\right)$, and $\mathrm{pH}$ were measured using a hand-held multi-probe water meter (YSI 556 MPS). These measurements were taken once every week. Water sample for ammonia measured in $\mathrm{mg} \mathrm{l}^{-1}$, were weekly collected and measured using a Palintest kit (Photometer 7100).

The fish were weighted every two weeks and their weight gain, specific growth rate, feed conversion rate and survival rate was calculated as follow:

$$
\begin{gathered}
\text { WG }(\%)=100 *(\mathrm{Wt}-\mathrm{Wi}) \\
\text { SGR }\left(\% \text { day }^{-1}\right)=100(\mathrm{LnWt}-\mathrm{LnWt}) / \mathrm{t} \\
\mathrm{FCR}=\mathrm{FI} / \mathrm{WI} \\
\text { Survival }(\%)=(\mathrm{FN} / \mathrm{FI}) * 100
\end{gathered}
$$

Where $\ln =$ natural logarithm,

$\mathrm{Wt}=$ final body weight $(\mathrm{g})$,

$\mathrm{Wi}=$ initial body weight $(\mathrm{g})$, and $\mathrm{t}=$ experiment duration time (days),

$\mathrm{FN}=$ total number of fish at the end of the experiment,

$\mathrm{FI}=$ total feed consumed $(\mathrm{g})$,

$\mathrm{WI}=$ weight increment $(\mathrm{g})$ and

$\mathrm{IN}=$ total number of fish stocked.

\subsection{Statistical Analysis}

All results are presented as mean \pm standard error of the mean (SEM). Data were analyzed by one-way analysis of variance (ANOVA) to test the effect of the experimental diets. Where significant differences were found at $(\mathrm{P}<0.05)$, a Turkey's test was used to determine which treatment means were significantly different from each other. The statistical analyses were made using XLSTAT (Version 2020: 5.1).

Table 1. Water quality parameters (mean \pm SEM) of the juvenile Oreochromis niloticus fed diets with different soybean levels ${ }^{l}(n=3)$.

\begin{tabular}{lllll}
\hline Weeks & Temperature $\left({ }^{\circ} \mathbf{C}\right)$ & $\mathbf{O}_{\mathbf{2}}\left(\mathbf{m g ~ I}^{\mathbf{1}}\right)$ & pH & Ammonia $\left(\mathbf{m g ~ ~ ^ { - 1 } )}\right.$ \\
\hline W1 & $21,91 \pm 0,10^{\mathrm{d}}$ & $7.07 \pm 1.42$ & $7,52 \pm 0,18$ & $0,03 \pm 0,04$ \\
W2 & $25,86 \pm 0,10^{\mathrm{a}}$ & $7,30 \pm 1,08$ & $7,350 \pm 0,22$ & $0,05 \pm 0,01$ \\
W3 & $21,62 \pm 0,00^{\mathrm{e}}$ & $7,19 \pm 0,10$ & $7,93 \pm 0,28$ & $0,14 \pm 0,10$ \\
W4 & $23,91 \pm 0,10^{\mathrm{c}}$ & $6,79 \pm 0,10$ & $7,33 \pm 0,48$ & $0,08 \pm 0,00$ \\
W5 & $21,38 \pm 0,10^{\mathrm{f}}$ & $6,51 \pm 0,30$ & $7,93 \pm 0,28$ & $0,14 \pm 0,13$ \\
W6 & $25,33 \pm 0,10^{\mathrm{b}}$ & $6,49 \pm 0,10$ & $7,93 \pm 0,28$ & $0,06 \pm 0,10$ \\
W7 & $17,05 \pm 0,10^{\mathrm{g}}$ & $6,19 \pm 0,20$ & $7,13 \pm 0,25$ & $0,07 \pm 0,14$ \\
W8 & $17,05 \pm 0,20^{\mathrm{g}}$ & $6,09 \pm 0,09$ & $6,91 \pm 0,40$ & $0,04 \pm 0,07$ \\
\hline
\end{tabular}

${ }^{1}$ Means \pm SD in the same column having the same superscript are not significantly different at $\mathrm{P}>0.05$. 


\section{Results}

\subsection{Water Quality Parameters}

Water quality parameters measurements are presented in Table 1. Except the temperature, no water quality parameter (dissolved oxygen, $\mathrm{pH}$ and Ammonia excretion) varied significantly $(p>0.05)$ during the experimental period. The water temperature varied significantly $((p<0.05)$ during the all period of the experimentation. The lowest water temperature was recorded at the last two weeks of the study.

\subsection{Growth Performance}

Initial weight, Final weight, per cent weight gain, specific growth rate, feed conversion ratio and survival values are summarized in Table 2. Final weight, specific growth rate and percent weight gain of fish increased significantly $(\mathrm{P}<$ 0.05 ) as soybean meal was added up to $30 \%$ level. The feed conversion ratio values were high and decreased significantly $(\mathrm{P}<0.05)$ with the increase of soybean meal in the diet, ranging from 2.17 to 2.90 . There was also a significant difference $(\mathrm{P}<0.05)$ in survival among treatment, survival ranged from $62.22 \%$ to $91.11 \%$. (Table 2 ).

Regarding the specific growth rate and the weight gain, the best growth performance is observed in fish fed the R2 diet containing $30 \%$ soybean meal, followed by the R3 diet containing $60 \%$ soybean meal.

Table 2. Growth performances (mean \pm SEM) of juvenile Oreochromis niloticus fed diets with different soybean levels ${ }^{l}$ ( $n=3$ ).

\begin{tabular}{lllllll}
\hline Treatment & IW & FW & WG & SGR & FCR \\
\hline T0 & $20 \pm 0,10$ & $31,80 \pm 0,7^{\mathrm{b}}$ & $58,86 \pm 3,58^{\mathrm{b}}$ & $0,77 \pm 0,04^{\mathrm{b}}$ & $2,17 \pm 0,15^{\mathrm{c}}$ & $91,11 \pm 3,85^{\mathrm{a}}$ \\
T1 & $20 \pm 0,10$ & $26,07 \pm 1,0^{\mathrm{c}}$ & $30,35 \pm 5,38^{\mathrm{a}}$ & $0,44 \pm 0,07^{\mathrm{c}}$ & $2,5 \pm 0,01^{\mathrm{b}}$ \\
T2 & $20 \pm 0,00$ & $35,97 \pm 0,1^{\mathrm{a}}$ & $79,98 \pm 0,48^{\mathrm{c}}$ & $0,97 \pm 0,00^{\mathrm{a}}$ & $62,22 \pm 7,7^{\mathrm{b}}$ & $2,63 \pm 0,06^{\mathrm{ab}}$ \\
T3 & $20 \pm 0,20$ & $33,03 \pm 0,0^{\mathrm{b}}$ & $65,36 \pm 0,43^{\mathrm{b}}$ & $0,83 \pm 0,00^{\mathrm{b}}$ & $75,55 \pm 10,18^{\mathrm{ab}}$ & $2,90 \pm 0,10^{\mathrm{a}}$ \\
\hline
\end{tabular}

${ }^{1}$ Means \pm SD in the same column having the same superscript are not significantly different at $P>0.05$.

\section{Discussion}

The protein requirement of tilapia ranges from 25 to $35 \%$ [3]. The crude protein content of the formulated diets in this study reached $35 \%$, therefore fulfilling this requirement.

Water quality parameters except the temperature were within the range of the culture conditions of O. niloticus. In [2] it was recommended an optimal temperature range of 20 to $35^{\circ} \mathrm{C}$ for fish farming. However [14-2] suggested that when considering this optimum for growth comparisons, it is also important to refer to the optimal O. niloticus-specific temperature of $24-32^{\circ} \mathrm{C}$.

The temperature was not controlled in our study due to the open system used and ranged from 17.05 to $25.86^{\circ} \mathrm{C}$, which was lower than the optimum for the cultured species. Temperature is the most critical water quality variable which affects a number of biological processes in fish culture systems [15]. Water temperature affects the physiology of fish, low water temperature leads to poor fish feeding, starvation, reduced growth and increased fish mortality, directly or indirectly. The decrease of growth was also reported by [16]. Who obtained a negative growth in low temperature (average of $15.6^{\circ} \mathrm{C}$ ) which they considered below the optimum threshold for this species.

Temperatures between 20 and $36^{\circ} \mathrm{C}$ have been reported by various researchers as being suitable for tilapia culture. According to [17], for instance, the preferred temperature range for optimum tilapia growth in ponds is between 25 and $27^{\circ} \mathrm{C}$. The preferred temperature ranges for tilapia have been reported to be between 31 and $36^{\circ} \mathrm{C}$ [18], while [19] gave a range between 20 and $35^{\circ} \mathrm{C}$ as ideal for tilapia culture. Water temperature is a key water quality variable because it influences all other water quality parameters such as dissolved oxygen concentrations.

The average dissolved oxygen ranged from 6.09 to 7.30 $\mathrm{mg}^{-1}$ during the entire study period of 60 days. According to [19], the preferred DO for optimum growth of tilapia is above $5 \mathrm{mg} / \mathrm{L}$.

Ammonia levels determined in this study ranged from 0.03 to $0.14 \mathrm{mg} \mathrm{l}^{-1}$ and were less than $0.5 \mathrm{mg} \mathrm{l}^{-1}$, which is considered tolerable for most farmed fish species [20, 21].

The $\mathrm{pH}$ level ranged from 6.91 to 7.93 and was within the recommended range $(6.5-9.0)$ of cultured species [19]. It can then be assumed that the observed mortalities are not related to water quality because of the low $\mathrm{pH}$ and low ammonia concentration. Prolonged exposure to unionized ammonia exceeding $0.2 \mathrm{mg} \mathrm{L}^{-1}$ is highly toxic to fish at $\mathrm{pH}$ levels above 9 and can lead to mass mortalities [22].

The SGR attained at the end of the study (after 56 days), ranged from $0.44-0.97 \%$ /day. Regarding the specific growth rate and the weight gain, the best growth performance is observed in fish fed the R2 diet containing 30\% soybean meal, followed by the R3 diet containing $60 \%$ soybean meal. The SGR value for the tilapia obtained in this study was similar with those obtained by [23] in their study, but lower than of Karina et a [3] where the SGR value was $1.36 \%$.

The effects of increasing soybean meal ratio in diet on growth and specific growth rate have been assessed in several studies and generally show that increased soybean meal lead to increased growth up to a certain level, beyond which growth rates level off, or even begin to decline [13, 9, 24]. The present study shows that for Nile tilapia, increasing soybean meal in diet leads to increased body weight gain and specific growth rates up to $30 \%$ inclusion, but also that no further improvement in growth rate and specific growth rate are achieved from 30 to $60 \%$ inclusion, indicating that $30 \%$ inclusion could represent a break point. The growth 
retardation could be attributed to unfavorable temperatures that did not support the optimal growth of $O$. niloticus. In addition, The poor growth observed in all treatments may be related to the presence of anti-nutritional factors present in the plant ingredients. The presence of anti-nutritional factors in materials of vegetable origin affects directly (trypsin inhibitors, phytic acids that complex phosphorus and make it indispensable) or indirectly (oligosaccharides, tannins, glucosinolates whose metabolites affect appetite and disrupt the synthesis of thyroid hormones), the digestive capacity of fish [25]. It is also known that soybean meal, even though it is considered the best source of vegetable protein in terms of amino acid profile, may not contain enough methionine to meet the essential amino acid requirements of fish [26].

The present study shows that FCR increases as soybean addition increases from 2.17 to 2.9. The high level of FCR observed in this study could be explained by the texture of homemade food pellets that lost nutrients through leaching into the water and worsened the feed conversion rate, which is contrary to the conclusion of [27], whose pellet texture improved the growth rate of $O$. niloticus. In addition, it is important to note that the amount of feed included in the FCR calculation can greatly exceed the amount actually consumed by the fish because, we assumed that the amount of feed distributed was totally consumed by the fish. It could be assumed that the poor performance could be due to the low degree of convertibility (by fish) of the ingredients of agricultural by-products used in food formulation.

Survival rate is usually influenced by food and environmental conditions. Bad food and environmental conditions will negatively affect the fish health and reduce the survival rate. The present study showed that the survival rate varies between 62.22 and $91.11 \%$ and that the best survival was observed with the commercial food. Apart from the control treatment, these mortalities can be considered high, as the survival rate generally accepted in fish farming is $90 \%$. Few mortalities was observed after the first weighing of control, the other was observed by the time and seems not to be due to the diets. Some mortalities were observed after the first control weigh, others were observed over time and do not appear to be diet-related.

\section{Conclusion}

In conclusion, dissolved oxygen, temperature, $\mathrm{pH}$ and ammonia in the experimental system were within the optimum range for growth of tilapia, while the temperature was not. The growth retardation was attributed to unfavorable temperatures that did not support the optimal growth of fish. The soybean meal may be added to up to $30 \%$ in the O. niloticus diet, without affecting growth performances.

\section{References}

[1] FAO. The State of World Fisheries and Aquaculture 2020. Sustainability in action. 224p.
[2] El-Sayed A. F. M., 2005 Environmental Requirements Temperature, Tilapia Culture, Egypt, CABI Publishing, pp. 34-38.

[3] Karina S., Akbar M., Supriatna A., Muchlisin Z. A., 2015 Replacement of soybean meal with Moringa oleifera leaf meal in the formulated diets of tilapia (Oreochromis niloticus) fingerlings. AACL Bioflux. 2015. 790-795.

[4] Kimou N. B., Koumi R. A., Koffi M. K., Atsé C. B., Ouattara I. N., Kouamé P. L., 2016 Utilisation des sous-produits agroalimentaires dans l'alimentation des poissons d'élevage en Côte d'Ivoire. Cah. Agric. 2016, 25, 25006: 1-9.

[5] Koumi A. R., Kimou N. B., Aste C. B., Ouattara I. N., Kouame P. L., 2015 Fish feeds used in Cote d'Ivoire, Nature, quality, use and productivity. Asian J. Agric. Food Sci, 3: 225- 236.

[6] Ogola M., Owiti D. O., Ominde J., 2020 Growth performance of Nile tilapia (Oreochromis niloticus) fingerlings fed on soybean (Glycine max) compared to dagaa (Rastrineobola argentea) meal with diet supplement of maize bran. J Fish Res; 4 (1): $14-20$.

[7] Ly M. A., Niang A. S., Ndiaye D., Ba C. T., 2019 Influence de la farine de feuille de Leucaena leucocephala dans l'alimentation des juvéniles de Oreochromis niloticus au Nord du Sénégal. Afrique Science 5 (2): 156-165.

[8] Bhosale S. V., Bhilave M. P., Nadaf S. B., 2010 Formulation of fish feed using ingredients from plant sources res Journal of Agricultural Science, 1 (3): 284-287.

[9] Ly M. A., Ba C. T., 2015 Effets d'une partielle substitution de la farine de poisson par la farine de soja sur la croissance des juvéniles de la perche du Nil (Lates niloticus, Linnaeus 1758). Int. J. Biol. Chem. Sci. 9 (3): 1477-1484.

[10] Cheng Z., Chen S., An M., Wang Q., Sun J., Fang Z., Xing K., 2018 Effects of replacing fish meal with soybean meal, with or without dietary arginine, on growth performance, immune indices and intestinal morphology of grouper, Epinephelus malabaricus. Aquaculture Research 49 (9) 2954-2964.

[11] Zhanga C., Rahimnejada S., Wanga Y., Lua K., Songa K., Wanga L., Mai K., 2018 Substituting fish meal with soybean meal in diets for Japanese seabass (Lateolabrax japonicus): Effects on growth, digestive enzymes activity, guthistology, and expression of gut inflammatory and transporter genes. Aquaculture, 483 173-182.

[12] Refstie S., Korsoen O. J., Storebakken T., Baeverfjord G., Lein I., Roem A. J., 2000 Differing nutritional responses to dietary soybean meal in rainbow trout Oncorhynchus mykiss and Atlantic salmon Salmo salar. Aquaculture, 190, pp. 49-63.

[13] Khan M. A., Jafri A. K., Chadha N. K., Usmani N., 2003 Growth and body composition of rohu (Labeo rohita) fed diets containing oilseed meals: partial or total replacement of fishmeal with soybean meal. Aquaculture Nutrition, 9, pp. 391-396.

[14] Crab R., Kochva M., Verstraete W., Avnimelech Y., 2009 Bioflocs technology application in overwintering of tilapia. Aquacultural Engineering 40, 105-112.

[15] Ogello E. O., Safina M. M., Christopher M. A., Jacob O. A., Jonathan M. M., 2014 An Appraisal of the Feasibility of Tilapia Production in Ponds Using Biofloc Technology: A review. International Journal of Aquatic Science, Vol. 5, No. 1, p. 21-39. 
[16] Estéves A., Treviño L., Kotzamanis Y., Karacostas I., Tort L-, Gisbert E., Effects of different levels of plant proteins on the ongrowing of meagre (Argyrosomus regius) juveniles at low temperatures. Aquaculture Nutrition. 2010; 17 (2): 572-582.

[17] Kausar R., Salim M., 2006 Effect of water temperature on the growth performance and feed conversion ratio of Labeo rohita. Pakistan Vet. J., 26 (3): 105-108.

[18] FAO. Fisheries and Aquaculture Department. 2011. Available at http://www.fao.Org/fishery/culturedspecies/Oreochromis_niloti cus/en Accessed 10.01.2021.

[19] Makori A. J., Abuom P. O., Kapiyo R., Anyona D. N., Dida G. O., 2017 Effects of water physico-chemical parameters on tilapia (Oreochromis niloticus) growth in earthen ponds in Teso North Sub-County, Busia County. Fisheries and Aquatic Sciences (2017) 20: 30 .

[20] Neori A., Chopin T., Troell M., Buschmann A. H., Kraemer G. P., Halling C., Shpigel M., Yarish C., 2004 Integrated aquaculture: rationale, evolution and state of the art emphasizing seaweed biofiltration in modern mariculture. Aquaculture 231, 361-391.

[21] Avnimelech Y., 2011 Tilapia production using biofloc technology: saving water, waste recycling improves economics. Global Aquaculture Advocate, p. 66-68.

[22] Nehemia A., Maganira J. D., Rumisha C., 2012 LengthWeight relationship and condition factor of Tilapia species grown in marine and fresh water ponds. Agriculture Biol. J. N. Am. 3 (3): 117-124.
[23] Handajani H.-, 2011 Optimalization of fermented Azolla meal substitution in fish diet to increase the productivity of tilapia]. Jurnal Teknik Industri 12 (2): 178-184 in Karina S, Akbar M, Supriatna A, Muchlisin ZA. 2015. Replacement of soybean meal with Moringa oleifera leaf meal in the formulated diets of tilapia (Oreochromis niloticus) fingerlings. AACL Bioflux. 2015. 790-795.

[24] Koch, J. F., Rawles S. D., Webster C. D., Cummins V., Kobayashi Y., Thompson K. R., Gannam A. L., Twibell R. G., Hyde N. M., 2016 Optimizing fish mealfree commercial diets for Nile Tilapia, Oreochromis niloticus. Aquaculture, 452: 357-366.

[25] Pham M. A., Lee K. J., Lim S. J., Park K. H., 2007 Evaluation of cottonseed and soybean meal as partial replacement for fishmeal in diets for juvenile Japanese olive flounder (Paralichthys olivaceus). Fisheries Science, 73: 760-769.

[26] Tantikitti C., Sangpong W., Chiavareesajja S., 2005 Effects of defatted soybean protein levels on growth performance and nitrogen and phosphorus excretion in Asian seabass (Lates calcarifer) Aquaculture, 248 (1-4), pp. 41-50.

[27] Bamba Y., Ouattara N., Ouattara S., Ouattara A., Gourene G., 2014 Effect of diets containing cocoa bean shell and coconut oil cake on the growth of Oreochromis niloticus (LINNE, 1758 ) in pond. International Journal of Biological and Chemical Sciences, 8 (4): 1368-1380. 